Atle Engebø, Erlend Andenæs, Tore Kvande, and Jardar Lohne (2018). "Governing Flat-Roof Constructions: A Case Study." In: Proc. $26^{\text {th }}$ Annual Conference of the International. Group for Lean Construction (IGLC), González, V.A. (ed.), Chennai, India, pp. 1079-1089. DOI: doi.org/10.24928/2018/0314. Available at: www.iglc.net

\title{
GOVERNING FLAT-ROOF CONSTRUCTIONS: A CASE STUDY
}

\author{
Atle Engebø ${ }^{1}$, Erlend Andenæs ${ }^{2}$, Tore Kvande ${ }^{3}$, and Jardar Lohne ${ }^{4}$
}

\begin{abstract}
A lean construction process depends on reliable procuring and governing of materials. This paper examines the case of flat roof constructions. It is based on an assumption that current practice might lead to a risk of premature roof failures. Within the case of flat roof constructions, we seek to answer the following research questions:

- What are the main threats to the value for the client in the case of flat-roof constructions?

- How does the client govern in order to oversee that requirements are met regarding construction materials- and assembling?

The research was explorative in nature and limited to the Norwegian context; based on a scoping literature study and seven semi-structured in-depth interviews with experienced industry actors. The findings show that in a short-term perspective, the divergence of stakeholder interest and premature roof failures present a great threat to the value of the building. Poor procuring and handling threatens the construction process. It is a source of disputes between the contractor and the client. Furthermore, it constitutes an obstacle in creating long-term value for the client. Flat-roof constructions are particularly exposed. We propose that clients should implement a more structured approach to overseeing that client requirements are met. To ensure a lean project delivery and maximizing value, mitigating unwanted events related to suppliers and materials are crucial.
\end{abstract}

\section{KEYWORDS}

Lean Construction, Value, Waste, Supply chain management, governance, safeguarding problems

$1 \quad$ Ph.D. student, Department of Civil and Environmental Engineering, Norwegian University of Science and Technology, Trondheim, Norway, +4790571902, atle.engebo@ntnu.no

2 Ph.D. student, Department of Civil and Environmental Engineering, Norwegian University of Science and Technology, Trondheim, Norway, erlend.andenas@ntnu.no

3 Professor, Department of Civil and Environmental Engineering, Norwegian University of Science and Technology, Trondheim, Norway, tore.kvande@ ntnu.no

4 Research scientist, dr. art. Department of Civil and Environmental Engineering, Norwegian University of Science and Technology, Trondheim, Norway, jardar.lohne@ ntnu.no 


\section{INTRODUCTION}

The aim of implementing lean principles and tools is to yield improvement in value for clients, users and producers (Ballard and Howell 2003; Drevland and Lohne 2015; Drevland et al. 2017; Hjelmbrekke et al. 2017). Some of the core principles are outlined in Howell's seminal paper on what lean construction actually entails. The essentials include a clear set of objectives for the project delivery process that aims at capitalising on performance to the best for the customer (Howell 1999). One essential, though oftenoverlooked, aspect of the project delivery process is supply chain management from a governance perspective. This may be understood as making sure the right materials are available to the on-site workforce, that the materials are of the intended quality and that their implementation is adequate. A delivery process aimed at creating value for the customer may be pulverized on the micro level by unsatisfactory procurement services, sloppy handling, and counterfeit, fraudulent or sub-standard (hereafter; CFSS) building materials. This paper addresses the intersection between governance, supply chain management and building physics.

More specifically, this paper examines the case of flat roof constructions. In Nordic climates, constructing flat roofs are more vulnerable to roofing defects than traditional pitched roofs, and largely avoided on small buildings if sloped, ventilated roofs can be built instead. As such, in Norway, flat roof constructions are mostly limited to large commercial or public buildings. The possibility of high snow loads makes flat roofs somewhat impractical for single-dwelling detached houses, which make up approximately 50\% of Norwegian residential buildings (Statistics Norway 2018). However, flat roofs see use on row houses and detached houses in functionalist style. The prevalence of single-dwelling houses in Norway sustains a large industry of local construction companies specializing in building them. Norwegian companies increasingly employing foreign labour, primarily from Eastern Europe, dominate this industry. The roof is usually the most exposed façade of a building, and its protection is crucial to secure the integrity of the rest of the structure. A study by Gullbrekken et al. (2016) revealed that roof defects made up $22 \%$ of all building defects investigated by the SINTEF Building and Infrastructure. Out of these were $19 \%$ on compact roofs and $28 \%$ on terraces.

The research presented is based on the assumption that current management practices during construction lead to an increased risk of using sub-par materials or errors occurring during assembling due to lack of proper workmanship. Governing these challenges is not a trivial task - and at the cornerstone of viable lean construction practices. Within the case of flat roof constructions, we address the following research questions:

- What are the main threats to the value for the client in the case of flat-roof constructions?

- How does the client govern in order to oversee that requirements are met regarding construction materials- and assembling? 


\section{METHODOLOGY}

The theoretical framework provides a review of academic literature related to flat-roof constructions, project governance- and procurement, CFSS-materials and supply-chain control, particularly within the field of lean construction. The literature review followed an approach as outlined by Denzin and Lincoln (1994), and Blumberg et al. (2011).

A case study approach with the use of interviews as the main source of collecting data was chosen (Blumberg et al. 2011; Yin 2013). The use of semi-structured interviews as prescribed by Creswell and Poth (2017) was considered convenient. An 'interview guide' was developed, covering the topics thought to be relevant for the outlined research purpose. The interview guide was structured according to the research questions. The respondent were encouraged to elaborate on topics beyond the interview guide.

The data collection took place between November 2017 and February 2018. Actors from different parts of the supply-chain were interviewed, focusing on the client perspective. These consisted of representatives from clients, suppliers, as well as one representative respectively from a major insurance company and the Norwegian Directorate for Building Quality. We alternated between executing the interviews face-toface and over the telephone/Skype. As described by Novick (2008) on the subject of telephone interviews, some researchers are concerned that a lack of physical representation could lead to data loss. These concerns, however, seems to be most valid for research related to fields such as psychology and medicine. On the contrary, telephone interviews could actually allow the respondent to reveal information more freely. All the interviews were recorded using an audio-recorder, a process accepted by all respondents. Transcriptions of the interviews were sent to the respondents respectively for acceptance. No data was used without acceptance of the respondents.

The study is limited to the case of flat-roof constructions. The context of the study was a seemingly growing concern in industry-specific newsprints regarding errors related to flat-roofs. One specific article, written by a supplier, and aimed at clients caught our attention(Icopal 2017). We, therefore, emphasized on the clients, with the purpose of increasing our insight into how clients consider such particular- and critical part of many building projects.

\section{LITERATURE REVIEW}

\section{FLAT ROOF CONSTRUCTIONS}

The majority of flat roofs are built as compact roofs covered with roofing membranes. Most commonly, the membranes are made using polymer-modified bitumen reinforced with polyester or glass-fibre sheets. Other materials used are based on polyvinylchloride (PVC) or rubber, with the same reinforcement of polyester or glass-fibre (Björk and Gränne 2000). Roof membranes are applied to the underlying surface using gluing, welding, ballasting or mechanical fastening, the latter being most common in Norway. Roofing may consist of one (single-ply) or two (double-ply) layers, welded or glued together. The primary purpose of roofing is to protect the underlying structure from 
weather damage, with moisture in the form of rainwater posing the greatest risk to the service life of components. Roof membrane application requires particular attention to the transitions between the roof and elements such as parapets, roof edges, drains, or other perforations(SINTEF Byggforsk 2008). The membrane itself will usually be waterproof, but water can leak through a faulty weld joint or transition, causing moisture damages that may not be detected easily. The primary degradation factors for roof membranes are elevated temperatures and UV radiation(Paroli et al. 1993; Rodriguez et al. 1993). To mitigate this, membranes may be covered in a white coating to reflect solar radiation. Other degradation factors include chemicals (in air pollution, salt spray or bird droppings) and mechanical wear (wind, hail or foot traffic).Gullbrekken et al. (2016) conducted research on roof defects in Norway, but with a focus on pitched, ventilated roofs. There appears to be a deficiency of research into the material supply aspect of roof defects.

\section{LEAN GOVERNANCE AND CONSTRUCTION PROCUREMENT}

In the perspective of literature on Lean Construction, several papers address governance. Banihashemi and Liu (2012) introduced the term 'lean governance'. They define 'lean governance' as "a specific combination of inter-organization relationships governance mechanisms that emphasizes social mechanisms and promotes valued relationships in the project". This approach was sought as a means to minimizing disputes and rework among others. The concept of governance is complex, and a plurality of definitions exist. In the following, we use the definition of Winch (2001), having the significant advantage of clear-cut analytic operationalisation: "the process of governance refers to practice on specific transaction sets: the micro analytical level." Here, the micro analytical level refers to governing the project process.

Alarcon et al. (1999) list a selection of problems detected in Chilean projects related to procurement. These include poorly planned inspections, lack of quality and suppliers failing to meet requirements. On aligning procurement with lean construction, Pekuri et al. (2014)maintain that value loss or uncertainty can be resolved by procurement procedures alone. Stating that procurement also involves procuring a production system, not just a final product, Pasquire et al. (2015) addressed what they referred to as 'safeguarding problem' in construction procurement. Defined by Rindfleisch and Heide (1997), a 'safeguarding problem' arises when a firm fears that its partner may opportunistically exploit their investment. Furthermore, Pasquire et al. (2015) categorize various safeguarding approaches within construction. They differentiate between 'conventional approaches' such as 'standard forms of contract' and 'less prevalent approaches' such as relational contracting. They emphasise that the industry favours conventional safeguarding approaches focusing on shifting risk, without the regard of the effects. Moreover, the clients' approach to procurement may lead to unnecessary costs, entrench wasteful processes both within the supply chain and through the project life cycle (Saad et al. 2017). Furthermore, Tillmann et al. (2014)urges that a shift from the "client x supplier" relationship into a "client + supplier" relationship may improve value creation for all parties. 


\section{MATERIAL FLOW, VALUE-DRIVEN PURCHASE, AND CONTROL}

Mastering the physical flow of materials is of utter importance for succeeding with construction projects. As stated by Agapiou et al. (1998), the supply of materials to the construction site has a significant effect on productivity. Several problems connect with the traditional flow of materials, for example, the practice of purchasing materials just before they are required, or purchasing in large quantities without compliance with actual needs on the constructions site (Agapiou et al. 1998). Childerhouse et al. (2000)argue that the purpose of supply chain management is not only waste reduction and cost cutting, but also customer satisfaction, which is a competitive advantage in itself. According to Alves et al. (2013), little has happened in the industry regarding supplier quality surveillance. These researchers suggest that Lean principles such as acting on root causes of problems, transparency, improving communication between supply chain members and helping suppliers improve could all improve current practice. An important aspect of choosing materials is their enormous potential effects on a building. Beyond their cost, materials have social, economic and environmental effects ranging from indoor environmental quality to waste production (Arroyo et al. 2016).

The academic literature concerning CFSS materials in the construction industry appears sparse, especially concerning roof/roof membrane solutions. The main provider of information on this topic related to the construction industry is the Construction Industry Institute (CII). The CII categorizes counterfeiting after types of products, ranging from Class A that are high-end goods very similar to the original, Class $\mathrm{C}$ that are obvious junk and easy to spot as fake, and Class B that are all products in-between(CII 2014; Minchin et al. 2010). Two major concerns arise: First, the possibility that such materials infiltrate the construction projects. Second, the possibility that they affect the process and the building. It creates wasteful activities such as need for rework- and control \& inspections, negatively affect the value and the value creation for all parties, and increases the risk of HSE-related problems both during and after construction (Engebø et al. 2017; Engebø et al. 2016; Kjesbu et al. 2017; Kjesbu et al. 2017). These results support the findings of the $\mathrm{CII}$ and Naderpajouh,concluding that detection of such materials prevents incidents related to safety and rework as well as associated risks to safety, cost and schedule(CII 2014; Minchin et al. 2010; Naderpajouh et al. 2015).

In sum, the CFSS-phenomena is crucial for mastering project governance and the supply-chain. Lean focus on relationships, shifting from transaction-based procurement to relationship-based procurement are threatened by the fact that some actors seek to exploit their partners concerning CFSS-materials.

\section{RESULTS AND DISCUSSION}

\section{THE MAIN THREATS TO FLAT-ROOF CONSTRUCTIONS}

Due to the relative complexity of such operations, the assembling of roof constructions is typically carried out by specialist roof-contractors. The risks involved in working on a tall roofs and the importance of securing a watertight roof all reinforce the impression that roofing work is "to be left to professionals". It was stressed by several of the interviewees 
that perforations and connections between structures were the most troublesome and vulnerable parts of a flat roof. Leaks are prone to happen where roofs meet walls or parapets. The problem is exacerbated for small or temporary building additions (such as adding a small overhanging roof to shelter baby strollers outside a kindergarten), where little money or time is invested into the project and quality control is all but absent; then again, the consequences of a leak in such cases tend to be accordingly small. In larger projects, faults may also occur. Few problems related to the roofing material itself were reported, but some interviewees noted that extreme climatic conditions might cause failures with roofing solutions that have been proven trustworthy elsewhere. One of the roof suppliers also noted that membranes in roof corners need extra reinforcement due to wind forces, but that this is not always applied.

Several of the interviewees also mentioned user failure as a potential threat to roof integrity. Insufficient snow removal and failure to replace aged membranes before they sprung a leak were repeatedly mentioned. Roof drains mounted on rigid drainpipes may even cause a "tent pole effect", where the drain itself becomes the only part of the roof that cannot be compressed by snow loads, thus becoming the highest part of the roof instead of the lowest. When the snow melts, the melt will not be drained away, and a donut-shaped pond forms around the drain. Interviewees noted that this is less of a problem if the drain is mounted on a "telescope drainpipe" or in a gutter. In extreme cases, snowmelt may also build up along parapets or walls, potentially exceeding the height at which the roof membrane is folded up along the wall, and then run down on the backside of the fold into the structure below. Potential causes for this are drain blockage, lack of overflow drains, ice build-up, or the fold being insufficiently high in the first place.

Foot traffic across the roof may also potentially damage it, particularly if stones or bits of metal are stuck under the sole of the person's shoes, as this may penetrate the roof membrane. Natural wear and tear of the roof membrane may be mitigated or exacerbated by material choice, design, and workmanship. For instance, the choice of fastening system is crucial in areas with excessive wind loads, and membranes may have to be reinforced with an extra layer where extra durability is required, such as in corners and traffic zones. Failure to recognize and compensate for climatic or other use conditions may lead to premature defects in otherwise well-built roofs.

\section{OVERSEEING THAT CLIENT REQUIREMENTS ARE MET}

In Design/Build projects(as often used by public clients in Norway, specialist contractors are procured as sub-contractors by the main contractor. The procurement is often strictly transaction-based with the lowest price as the key evaluation criteria. Several problems might occur using this delivery model. In extreme cases, fraudulent behaviour is experienced. Such behaviour is exemplified by sub-contractors providing certificates related to a "product A", but uses "product B" during assembling. Thus, the client assuming he gets "product A" which satisfies his needs, instead "product B" with unknown properties is used. Often, clients have little knowledge, or influence over subcontractors used in the project. This could result in insufficient control over material choices, or the assembling of flat roof constructions. Moreover, such aspects of building 
projects are critical for the lasting value of the building. Substandard flat-roofs might result in a variety of problems for the client during the building's lifetime and often cause a need for earlier-than-planned refurbishment of the building.

According to the interviewee from the insurance company, serious actors often fix claims without involving the insurance company. This is in contrast to so-called 'bankruptcy runners', who initiate projects and file for bankruptcy within the year. Under such conditions, the insurance provider is often held responsible for the whole claim. The interviewees emphasised the importance of having favourable construction insurance, a traditional safeguarding approach, in order to mitigate the unwanted risk from unserious actors and dubious workmanship. By creating a setting where every actor is focusing on shifting the risk, disputes will eventually involve a multiparty of actors in the supplychain. Involving a multiparty of actors creates a wasteful and tedious process resulting in unnecessary costs within the supply-chain and the project.

In the case of flat-roof constructions, problems related to CFSS-materials seem to be discovered by coincidence (for example sparkled by a suspicion by a competitor). In reality, neither the contractor nor the client has the needed resources to control every delivery or the documentation of every material used in a project. As stated by several interviewees, Norwegian clients put an extensive amount of trust into their chosen contractor. The trust seems correlated to the expectation of the final product, i.e. the finished building, with little emphasis on the contractor's execution model. In other words, it seems that clients have little competence, or maybe willingness, to study exactly how the contractor delivers value. When the client chooses a delivery model, they tend to choose models that shift risk and minimize contractual relationship (i.e. one contract with the main contractor). Thus, avoiding concerns with sub-contractors and material choices.

Figure 1. shows an illustration of our findings. There are undoubtedly problems related to flat-roofs, problems that affect the value of the client. Furthermore, due to their complexity, flat-roofs should be viewed as a critical part of the delivery. Clients seem to focus on shifting risk when choosing the delivery model. Thus, when asked about governance during construction they tend to emphasize that the responsibility is with the contractor. Finally, when asked about previous experiences with erroneous roofs, everyone has a narrative to describe. The narrative often resembles that of a Greek tragedy, a construction of suffering and insight. 


\begin{tabular}{|c|c|c|}
\hline $\begin{array}{c}\text { Are projects safeguarded against unwanted } \\
\text { events regarding roofing tod ay? } \\
\text { «No, it is not. When talking about roofing, it is } \\
\text { the contractor who largely decides what is being } \\
\text { used.» } \\
\text { «In most cases, there is no one who control what } \\
\text { they add. Of course, there are a few that do, but } \\
\text { not in general.» }\end{array}$ & $\begin{array}{l}\text { Who is respon sible for controlling the quality } \\
\text { of the materials? } \\
\text { «We are not sure, it is the responsibility of the } \\
\text { contractor. Material suppliers are not someone } \\
\text { we have contact with, it is the contractor's } \\
\text { responsibility. As long as they deliver the } \\
\text { products that are to be delivered and they meet } \\
\text { the requirements, that's not an issue.» }\end{array}$ & $\begin{array}{l}\text { The reality of the problem: } \\
\text { A study by Gullbrekken et al. (2016) revealed that } \\
\text { roof defects made up } 22 \% \text { of all building defects } \\
\text { investigated by SINTEF. }\end{array}$ \\
\hline Selecting appropriate project delivery method & onstruction & Handover and into the utilisation phase \\
\hline $\begin{array}{l}\text { How can you avoid it? } \\
\text { «The problem is when you are just considering } \\
\text { price, picking up five to six bids and choosing the } \\
\text { lowest price.»(..) «We can make specific } \\
\text { requirements regarding critical material, where } \\
\text { we want to see the Supply-chain from the specific } \\
\text { elements to the finished product, for example } \\
\text { through the use of EPD» }\end{array}$ & $\begin{array}{l}\text { What control mechanisms exist today } \\
\text { regarding m aterials on the construction site? } \\
\text { "That's a random check then. But we have a very } \\
\text { strongly confident that the materials delivered to } \\
\text { the construction site are according to } \\
\text { specification. But we do random sampling } \\
\text { sometimes.» }\end{array}$ & $\begin{array}{l}\text { Do you experience erroneous roofs? } \\
\text { «We experience most of the damage at the end of } \\
\text { the lifecycle, after } 25-30 \text { years or so. Errors from } \\
\text { the execution are uncovered quite quickly. We } \\
\text { usually have proper control of what is happening } \\
\text { around takeover. Something is being corrected } \\
\text { during the warranty period.» }\end{array}$ \\
\hline
\end{tabular}

Figure 1: An illustration of some of the findings

A potential long-term solution is, as described by Alves et al. (2013) and Pasquire et al. (2015), to change the focus from just shifting the risk from one another to instead focusing on the root cause of the problem. Thus, focusing on soft elements such as improving communication, transparency and helping sub-contractors improve their own practice.

\section{CONCLUSION}

Premature roof failures present a great threat to the value of a roof, especially so if the failure is not discovered and repaired before excessive moisture damage has happened underneath the roof membrane. There can be many causes of failure. According to interviewees, design flaws and construction errors are more common than material faults. Perforations and transitions of the roofing material stand out as the most risky elements on a roof. Additionally, failure to maintain the roof may also cause roof defects. When asked about CFSS-materials in flat-roof constructions, the findings show that neither clients nor suppliers had substantial knowledge or experience with this phenomenon. This is a worrying finding bearing in mind the assortment of consequences described in the literature.

In the context of such complicated constructions as flat-roofs, both the client and the responsible contractors need to be aware of the possible risks. Often specialist contractors procured sub-contractors that have the main responsibility for flat-roof constructions. There seems to be a real prospect that emerging forms of project procurement arrangements such as relational contracting that emphasise on lean principles - such as the focus on people, relationships, and integration - may prove to be more effective in counteracting problems revealed than the conventional methods are. Thus, we propose that clients should implement a more planned approach to overseeing that client requirements are met. To ensure a lean project delivery, mitigating unwanted events related to material choice, design, and workmanship is necessary. 
Future research should be directed towards the perspective of the sub-contractors that specialises in constructing flat-roofs. Especially focusing on supply-chain management and the relation between the sub-contractor and the main-contractor and the client. Several of the interviewees suspected that conditions were "less tidy" in the part of the industry focusing on smaller-scale (i.e. single dwelling residential) projects. While the large actors interviewed in this article have greater amounts of data and a better overview of the many requirements of a construction process, interviews with small-scale actors may give a better insight into the smaller and less organized side of the industry - if only on a local level.

\section{REFERENCES}

Agapiou, A., Clausen, L. E., Flanagan, R., Norman, G., and Notman, D. (1998). "The role of logistics in the materials flow control process." Construction Management and Economics, 16(2), 131-137.

Alarcon, L. F., Rivas, R., and Serpell, A. (1999). "Evaluation and Improvement of the Procurement Process in Construction Projects." Proc., 7th Annual Conference of the International Group for Lean Construction Berkeley, USA, 219-230.

Alves, T. d. C. L., Walsh, K. D., Neuman, Y., Needy, K. L., and Almaian, R. (2013). "Supplier Quality Surveillance Practices in Construction." Proc., 21th Annual Conference of the International Group for Lean Construction Fortaleza, Brazil, 833-842.

Arroyo, P., Tommelein Iris, D., and Ballard, G. (2016). "Selecting Globally Sustainable Materials: A Case Study Using Choosing by Advantages." Journal of Construction Engineering and Management, 142(2), 05015015.

Ballard, G., and Howell, G. (2003). "Lean project management." Building Research \& Information, 31(2), 119-133.

Banihashemi, S. Y., and Liu, L. (2012). "'Lean Governance" : A Paradigm Shift in InterOrganizational Relationships (IORs) Governance." Proc., 20th Annual Conference of the International Group for Lean Construction San Diego, USA.

Björk, F., and Gränne, F. (2000). "Roof membranes-The Swedish practice in light of EOTA TB 97/24/9.3. 1 PT3 Durability." Materials and Structures, 33(4), 270-277.

Blumberg, B., Cooper, D. R., and Schindler, P. S. (2011). Business research methods, McGraw-Hill Higher Education, London.

Childerhouse, P., Hong-Minh, S. M., and Naim, M. M. (2000). "Selecting The Right Strategy To Meet Customer Requirements." Proc., 8th Annual Conference of the International Group for Lean Construction Brigthon, UK.

CII (2014). "Mitigating Threats of Counterfeit Materials in the Capital Projects Industry." Construction Industry Institute (CII).

Creswell, J. W., and Poth, C. N. (2017). Qualitative inquiry and research design: Choosing among five approaches, Sage publications.

Denzin, N. K., and Lincoln, Y. S. (1994). Handbook of qualitative research, Sage, Thousand Oaks, Calif. 
Drevland, F., and Lohne, J. (2015). "Nine Tenets on the Nature of Value." Proc., 23th Annual Conference of the International Group for Lean Construction (IGLC).

Drevland, F., Lohne, J., and Klakegg, O. J. (2017). "Ethical Dilemmas In Value Delivery: Theoretical Conditions." Proc., 25th Annual Conference of the International Group for Lean Construction (IGLC).

Engeb $\varnothing$, A., Kjesbu, N., Lædre, O., and Lohne, J. (2017). "Perceived Consequences of Counterfeit, Fraudulent and Sub-standard Construction Materials." Procedia Engineering, 196, 343-350.

Engebø, A., Lohne, J., Rønn, P. E., and Lædre, O. (2016). "Counterfeit Materials in the Norwegian AEC-Industry." Proc., 24th Annual Conference of the International Group for Lean Construction Boston, USA.

Gullbrekken, L., Kvande, T., Jelle, B., and Time, B. (2016). "Norwegian Pitched Roof Defects." Buildings, 6(2), 24.

Hjelmbrekke, H., Klakegg, O. J., and Lohne, J. (2017). "Governing value creation in construction project: a new model." International Journal of Managing Projects in Business, 10(1), 60-83.

Howell, G. A. (1999). "What is lean construction-1999." Proc., Proceedings of the seventh annual conference of the international group for lean construction, Citeseer, 1-10.

Icopal (2017). "Flat roofs - so wrong can it go " Byggeindustrien, Byggeindustrien, http://www.bygg.no.

Kjesbu, N. E., Engeb, A., Lædre, O., and Lohne, J. (2017). "Countering counterfeit, fraudulent and sub-standard materials in construction." Proc., Computer Sciences and Information Technologies (CSIT), 2017 12th International Scientific and Technical Conference on, IEEE, 92-99.

Kjesbu, N. E., Engeb $\varnothing$, A., Lædre, O., and Lohne, J. (2017). "Counterfeit, Fraudulent and Sub-Standard Materials: The Case of Steel in Norway." Proc., 25th Annual Conference of the International Group for Lean Construction Heraklion, Greece, 805-812.

Minchin, R., Walters, R., Pan, J., Dvorsek, J., Traffanstead, D., Casada, M., and Kelly, T. (2010). "Product integrity concerns in low-cost sourcing countries." Construction Industry Institute, Austin, TX.

Naderpajouh, N., Hastak, M., Gokhale, S., Bayraktar, M. E., Iyer, A., and Arif, F. (2015). "Counterfeiting Risk Governance in the Capital Projects Supply Chain." Journal of Construction Engineering and Management, 141(3), 04014084.

Novick, G. (2008). "Is There a Bias Against Telephone Interviews In Qualitative Research?" Research in nursing \& health, 31(4), 391-398.

Paroli, R., Dutt, O., Delgado, A., and Stenman, H. (1993). "Ranking PVC roofing membranes using thermal analysis." Journal of materials in civil engineering, 5(1), 83-95.

Pasquire, C., Sarhan, S., and King, A. (2015). "A Critical Review of the Safeguarding Problem in Construction Procurement: Unpicking the Coherent Current Model." Proc., 23rd Annual Conference of the International Group for Lean Construction Perth, Australia, 309-318. 
Pekuri, L., Pekuri, A., and Haapasalo, H. (2014). "Analysing the Problem of Procurement in Construction." Proc., 22nd Annual Conference of the International Group for Lean Construction Oslo, Norway, 39-50.

Rindfleisch, A., and Heide, J. B. (1997). "Transaction Cost Analysis: Past, Present, and Future Applications." Journal of Marketing, 61(4), 30-54.

Rodriguez, I., Dutt, O., Paroli, R., and Mailvaganam, N. (1993). "Effect of heat-ageing on the thermal and mechanical properties of APP-and SBS-modified bituminous roofing membranes." Materials and Structures, 26(6), 355-361.

Saad, S., Christine, P., Emmanuel, M., and Andrew, K. (2017). "Contractual governance as a source of institutionalised waste in construction: A review, implications, and road map for future research directions." International Journal of Managing Projects in Business, 10(3), 550-577.

SINTEF Byggforsk (2008). "SINTEF Building Research Design Guides 544.204,." Tekking med asfalttakbelegg eller takfolie. Detaljlфsninger, SINTEF Byggforsk, https://byggforsk.no.

Statistics Norway (2018). "Statistics: Construction, housing and property > Dwellings." <https://www.ssb.no/en/bygg-bolig-og-eiendom/statistikker/boligstat>. (2018).

Tillmann, P., Berghede, K., Ballard, G., and Tommelein, I. D. (2014). "Developing a Production System on IPD: Considerations for a Pluralistic Environment." Proc., 22nd Annual Conference of the International Group for Lean Construction Oslo, Norway, 317-328.

Winch, G. M. (2001). "Governing the project process: a conceptual framework." Construction Management and Economics, 19(8), 799-808.

Yin, R. K. (2013). Case study research: Design and methods, SAGE Publications Inc. 